\title{
Genetic Analysis of Adult-Plant Resistance to Leaf Rust in Five Spring Wheat Genotypes
}

\author{
A. Navabi, Department of Agricultural, Food, and Nutritional Science, 4-10 Agriculture/Forestry Center, University \\ of Alberta, Edmonton, AB, T6G 2P5, Canada; R. P. Singh, CIMMYT, Apdo, 6-641, 06600 Mexico, DF, Mexico; \\ and J. P. Tewari and K. G. Briggs, Department of Agricultural, Food, and Nutritional Science, University of Al- \\ berta, Canada
}

\begin{abstract}
Navabi, A., Singh, R. P., Tewari, J. P., and Briggs, K. G. 2003. Genetic analysis of adult-plant resistance to leaf rust in five spring wheat genotypes. Plant Dis. 87:1522-1529.

Inheritance of adult-plant resistance to leaf rust, caused by Puccinia triticina, was studied in the progeny of a one-way diallel cross involving five CIMMYT-derived adult-plant resistant wheat (Triticum aestivum) genotypes and a susceptible wheat 'Avocet- $Y r A^{\prime}$ '. $\mathrm{F}_{1}$ progenies, $\mathrm{F}_{2}$ populations, $\mathrm{F}_{2}$-derived $\mathrm{F}_{3}$, and $\mathrm{F}_{4}$-derived $\mathrm{F}_{5}$ lines were field evaluated under artificial epidemics with leaf rust race $\mathrm{MCJ} / \mathrm{SP}$. Adult-plant resistance to leaf rust was incompletely dominant in crosses with the susceptible parent and was found to be controlled by additive interactions of $2 r 34$ with at least two to three additional genes. Transgressive segregation giving rise to plants or lines with higher and lower levels of resistance than the parents was observed in all $\mathrm{F}_{2}$ and $\mathrm{F}_{5}$ derivatives of the resistant-parent intercrosses and suggested that, apart from Lr34, some of the other additive genes were nonallelic. Although specific combining ability was significant in some generations, general combining ability was found to be the major component of variation. Among generations, the estimates of the narrow-sense heritability of adult-plant resistance to leaf rust ranged from 0.67 to 0.97 .
\end{abstract}

Additional keywords: diallel analysis

Leaf rust, caused by Puccinia triticina Eriks., is the most widely distributed and most common of all three wheat rusts (24). On a worldwide basis, it probably causes more yield losses than the other wheat rusts (25). Khan et al. (13) determined that, for leaf rust severities of up to approximately $20 \%$, every $1 \%$ of the flag leaf area covered by rust pustules caused a reduction of $1 \%$ in grain yield in winter wheat cultivars grown in Mississippi. However, losses to leaf rust are highly influenced by the growth stage at disease onset (24). Chemical control of leaf rust often is practically unmanageable and uneconomical. Genetic resistance is the most economical method of reducing yield losses due to leaf rust (14). Most of the catalogued leaf rust resistance genes (19)

Corresponding author: J. P. Tewari

E-mail: JP.Tewari@ualberta.ca

The Ph.D. fellowship of A. Navabi was supported through funds provided to CIMMYT by the Agricultural Research and Education Organization of the Ministry of Agriculture, Iran. Operational expenses of this research in Mexico were funded by CIMMYT, and those in Canada were funded through a Matching Grant from the Alberta Agricultural Research Institute.

Accepted for publication 22 August 2003.

Publication no. D-2003-1009-03R

(C) 2003 The American Phytopathological Society confer race-specific hypersensitive responses that remain effective for a short period of time, but may then become ineffective as races with virulence to the resistance genes develop in the pathogen population.

Substantial economic benefits are likely to be associated with the development of race-nonspecific resistance to leaf rust in many wheat-producing areas, especially in areas where farmers change cultivars slowly (37). Race-nonspecific adult-plant resistance to leaf rust, often referred to as slow rusting (6) or partial resistance (21), is characterized as a type of interaction between the host plant and pathogen in which plants show less disease severity compared with the susceptible check, despite compatibility or susceptible infection types. Several studies report the inheritance of such resistance to leaf rust $(3,4,8,16,20,35)$. Genetic studies based on either latent period or the area under the leaf rust progress curve often have shown that race-nonspecific adult-plant resistance to leaf rust is under oligogenic or polygenic control of genes having additive effects with relatively high heritability $(8,16,27)$.

Durable resistance to leaf rust often involves race-nonspecific, additive adultplant resistance genes (18). Attempts have been made in several wheat breeding programs to accumulate additive resistance genes into high-yielding wheat back- grounds to achieve higher levels of racenonspecific resistance. Resistant parental genotypes studied in this research were developed in a breeding project at the International Wheat and Maize Improvement Center (CIMMYT), aimed at combining as many additive resistance genes as possible through intercrossing adult-plant resistant genotypes. Genotypes were selected for the high seedling infection type accompanied by low leaf rust severities in the adult stage (32).

The objectives of the present research were to (i) determine the number of genes that confer a high level of adult-plant resistance to leaf rust and (ii) study the combining abilities and gene effects involved in such resistance in five wheat genotypes.

\section{MATERIALS AND METHODS}

Plant material. Five adult-plant resistant genotypes and a susceptible genotype, 'Avocet-YrA' (Table 1), were intercrossed in a one-way diallel mating design in a greenhouse at the University of Alberta, Edmonton, Canada. Avocet- $Y r A$ is a reselection from the Australian cv. Avocet that shows high susceptibility to current leaf rust races in Mexico, where field experiments were carried out. Crosses were made by hand-emasculation and artificial pollination using the approach method (1). Parental genotypes were planted in 15-cmdiameter pots filled with a Metro-mix (W. R. Grace \& Co., Ajax, Ontario, Canada) soil mixture and grown in a greenhouse maintained at 20 and $15^{\circ} \mathrm{C}$ (day and night, respectively) and a $16-\mathrm{h}$ photoperiod. From each cross, 90 to $150 \mathrm{~F}_{1}$ seed were harvested. Ten $F_{1}$ seed from each cross were grown in a greenhouse with the same growing conditions as mentioned for crossing, and self-fertilized to produce $\mathrm{F}_{2}$ seed that were harvested from individual plants in each cross. Consequently, $\mathrm{F}_{2}$-derived $\mathrm{F}_{3}$ lines of the susceptible $\times$ resistant crosses were harvested from $\mathrm{F}_{2}$ single plants that were planted in the greenhouse. The $F_{5}$ single seed-descent lines of the diallel cross were developed by advancing generations using the single seed-descent method (23). In each generation, single plants of the crosses were grown in root containers (25 $\mathrm{mm}$ in diameter and $140 \mathrm{~mm}$ deep) containing Metro-mix. One seed was harvested from each single plant in each generation and replanted to achieve the next 
generation. The $\mathrm{F}_{4}$ seed were space planted at the University of Alberta Edmonton Research Station in the summer of 2000 and $\mathrm{F}_{5}$ single seed-descent lines were harvested from single $\mathrm{F}_{4}$ plants.

Test sites. Field evaluations were carried out at two CIMMYT Research Stations. The first was at El-Batan (Mexico State) in the highlands of central Mexico $\left(19^{\circ} \mathrm{N}, 2,249 \mathrm{masl}\right)$ during the 2000 crop season, starting in mid-May and concluding in early October. The second was at Ciudad Obregon (Sonora State) in northwestern Mexico $\left(22^{\circ} \mathrm{N}, 7 \mathrm{masl}\right)$ during the winter 2000-01 crop season, starting in late November and concluding in early April. Each site has a favorable environment for leaf rust development.

Experimental procedure. Parental lines, $F_{1}$ progenies, $F_{2}$ populations derived from the diallel crosses, and $\mathrm{F}_{3}$ lines from the susceptible $\times$ resistant crosses were evaluated at El-Batan during the summer 2000 crop season. $F_{1}$ and $F_{2}$ diallel experiments, comprising six parental lines and 15 $\mathrm{F}_{1}$ crosses or $\mathrm{F}_{2}$ populations, were planted separately, each in a three-replication randomized complete block design. Fifteen seed were planted in each $F_{1}$ experimental unit on a double-row bed, $1 \mathrm{~m}$ long and 70 $\mathrm{cm}$ wide. In each $\mathrm{F}_{2}$ experimental unit, 120 seed were space-sown, about $10 \mathrm{~cm}$ apart, on two double-row beds, $3 \mathrm{~m}$ long and 75 $\mathrm{cm}$ wide. The $\mathrm{F}_{3}$ lines of the susceptible $\times$ resistant crosses (52 to 80 lines from each cross) were planted in one replication with plot sizes similar to the $F_{1}$ experiment, with parental lines repeated after every 10 lines as checks. Each $\mathrm{F}_{3}$ line was grown in an individual plot with $3 \mathrm{~g}$ of seed planted to obtain at least 60 plants per plot.

The experimental design used for planting $\mathrm{F}_{3}$ and $\mathrm{F}_{5}$ lines at Ciudad Obregon during 2000-01 was an augmented randomized complete block design where 10 check genotypes (Table 2) were planted in 3 and 10 replications of $F_{3}$ and $F_{5}$, respectively. Each of these replications formed a complete block. Unassigned plots then were formed within each block and were filled with unreplicated experimental lines (27). The six parental lines, a total of 564 $\mathrm{F}_{3}$ lines from the susceptible $\times$ resistant crosses (66 to 155 lines from each cross), and $1,802 \mathrm{~F}_{5}$ lines from the diallel cross
(76 to 142 lines from each cross) were included in this test. Each block, comprising 200 experimental units, included 190 lines and 10 checks. Plot size and seed density were the same as in the $\mathrm{F}_{3}$ experiment at El-Batan. The $\mathrm{F}_{3}$ lines included in the Ciudad Obregon study were different from those studied at El Batan.

Artificial epidemics and LR race. In all field experiments, one row of the highly susceptible cv. Morocco was planted as spreader on one side of the plots in the middle of the 0.5 -m-wide pathways and around the field. Artificial inoculation was carried out with the Mexican P. triticina race MCJ/SP (28) by spraying the spreader rows with urediniospores suspended in a light-weight mineral oil Soltrol-170 (Bartlesville, OK) with $300 \mathrm{mg}$ of spores per liter of oil, about 4 and 6 weeks after planting at El-Batan and Ciudad Obregon, respectively. Fresh inoculum was obtained by multiplying urediniospores on the susceptible cv. Morocco in a greenhouse. According to Singh (28), race MCJ/SP has the following avirulence/virulence formula: Lr2a,2b,2c,3ka,9,16,19,21,24,25,28,29,30, $32,33 / 1,3,3 b g, 10,11,12,13,14 a, 14 b, 15,17$, $18,20,22 b, 23,26,27+31$.

The race MCJ/SP was considered suitable for the study of adult-plant resistance to leaf rust because all parents included in this study show a high (susceptible) infection type in the seedling tests and reduced leaf rust severity as adults in field tests (Table 1) with it.

Leaf rust assessment. Leaf rust severities were assessed visually twice following the modified Cobb's scale (22). Based on the practice used in CIMMYT (36), the first rating was done when the leaf rust severity of the susceptible parent, Avocet$Y r A$, reached 80 to $100 \%$ and the second rating was done 10 to 15 days later, when the leaves of the susceptible parent had dried out due to leaf rust infection. $F_{1}$ progenies and $\mathrm{F}_{3}$ and $\mathrm{F}_{5}$ lines were assessed based on the average rust severity on the flag and penultimate leaves in a plot. For this purpose, several leaves were examined and an overall visual estimate of the disease severity was recorded for each plot. In the $\mathrm{F}_{2}$ diallel experiment, however, single plants in each plot were rated separately for disease severity. Flag and penultimate leaves of the two most advanced tillers of each plant were observed, to determine the average severity estimate of each $\mathrm{F}_{2}$ plant. Average leaf rust severity for each $\mathrm{F}_{2}$ plot then was computed.

Genetic analysis. For the segregation analysis, $\mathrm{F}_{3}$ lines of the susceptible $\times$ resistant crosses were classified into four phenotypic groups: homozygous for the parental type resistance (HPTR), homozygous for the parental type of higher susceptibility (HPTS), either segregating or homozygous for disease levels higher than the resistant parent but less than the susceptible parent (SegI), and segregating for disease levels equal to the susceptible parent (SegS). The $\mathrm{F}_{5}$ lines were classified into three groups: HPTR, HPTS, and other segregants. HPTR lines were assumed to be derivatives of the $F_{2}$ or $F_{4}$ single plants homozygous for all resistance alleles; HPTS lines were assumed to be the derivatives of the $\mathrm{F}_{2}$ or $\mathrm{F}_{4}$ single plants homozygous for all susceptibility alleles; SegI lines were assumed to be the derivatives of the $F_{2}$ single plants homozygous for resistance allele for at least one locus; and SegS lines were assumed to be the derivatives of the $\mathrm{F}_{2}$ or $\mathrm{F}_{4}$ single plants heterozygous for resistance allele for at least one locus and homozygous for susceptibility alleles at all other loci. To test the distribution of the observed phenotypic frequencies against those expected for segregation models, $\chi^{2}$ analyses were carried out.

Quantitative genetic analyses were performed on the mean values of the terminal leaf rust severities of experimental units, separately for the $F_{1}, F_{2}$, and $F_{5}$ diallel experiments, and for the susceptible $\times$ resistant crosses in the $F_{3}$ generation, tested in Ciudad Obregon. The residuals were not normally distributed as determined by the Proc UNIVARIATE procedure (SAS Institute, Cary, NC). Therefore, mean disease severity of each plot was transformed by the arcsine of the square root to normalize the scale. Analyses of variance (38) were performed for the terminal leaf rust severities separately for the $\mathrm{F}_{1}, \mathrm{~F}_{2}, \mathrm{~F}_{3}$, and $\mathrm{F}_{5}$ experiments, with treatments being parents and crosses in $F_{1}$ and $\mathrm{F}_{2}$ and parents, crosses, and checks in $\mathrm{F}_{3}$ and $\mathrm{F}_{5}$. For the unbalanced $\mathrm{F}_{3}$ - and $\mathrm{F}_{5}$-line experiments, analyses of variance were performed following the model for the augmented design proposed by Scott and

Table 1. Wheat genotypes included in genetic analysis with their pedigree, and adult-plant and seedling responses to Puccinia triticina race $\mathrm{MCJ} / \mathrm{SP}$

\begin{tabular}{|c|c|c|c|}
\hline \multirow[b]{2}{*}{ Genotype } & \multirow[b]{2}{*}{ Cross and selection history } & \multicolumn{2}{|c|}{ Leaf rust response } \\
\hline & & Adult plant & Seedling $\mathrm{z}$ \\
\hline Avocet- $Y r A$ & WW191/WW15//Egt & Susceptible & 4 \\
\hline Saar & Sni/Trap\#1//Bav92 CG25-099Y-099M-4Y-2M-3Y-0B & Resistant & $3-4$ \\
\hline Simorgh & Sni/Yaco//Bav92 CG29-099Y-099M-10Y-2M-3Y-0B & Resistant & $3-4$ \\
\hline Homa & HD2281/Yaco/3/Kauz*2/Trap//Kauz CG54-099Y-099M-10Y-3M-5Y-0B & Resistant & $3-4$ \\
\hline Parastoo & Pvn//Car422/Ana/3/Kauz*2/Trap//Kauz CG62-099Y-099M-3Y-3M-3Y-0B & Resistant & $3-4$ \\
\hline Cocnoos & Trap\#1/PBW65//Star CG99-099Y-099M-3Y-7M-1Y-0B & Resistant & $3-4$ \\
\hline
\end{tabular}

${ }^{\mathrm{z}}$ Seedling responses are infection types based on a 0-to-4 scale (24) where infection types 3 and 4 are considered compatible or susceptible. 
Milliken (26). Minor modifications were made in order to estimate the effects of treatment and line-treatment; to break the sum of squares for treatment into parents, effect of parents versus crosses using a single-degree of freedom contrast (SAS Institute). Combining ability analyses were IV of Griffing (12) with treatment as fixed effect. Parents were not included in the combining ability analyses, to obtain unbiased estimates of general combining ability (GCA) and specific combining ability (SCA) parameters $(7,30)$. Diallel Analysis and Simulation Software (5) was used to estimate the GCA and SCA effects and the components of variance. Narrow-sense heritability of adult-plant resistance to leaf rust was estimated separately for each generation as the ratio of additive variance to phenotypic variance. crosses, and checks; and to estimate the performed following the model I, method

Mean terminal leaf rust severities of genotypes were computed for the $\mathrm{F}_{1}$ and $\mathrm{F}_{2}$ diallels using the MEANS statement in the Proc GLM procedure (SAS Institute). However, because the $F_{3}$ and $F_{5}$ experiments were unbalanced, least square means were computed for each genotype, using LSMEANS statement in Proc GLM procedure (SAS Institute).

Minimum numbers of additive genes in the resistant parents were estimated based on the formula proposed by Bjarko and Line (3), using data from the $\mathrm{F}_{5}$ experiment: $N=(G R)^{2} / 4.27\left(V_{F 5}-\left[V_{P 1}+V_{P 2}\right] / 2\right)$, where $N$ is the minimum number of effective additive genes, $G R$ is the genotypic range, $V_{\mathrm{F} 5}$ is the variance of the $\mathrm{F}_{5}$ lines, and $V_{\mathrm{P} 1}$ and $V_{\mathrm{P} 2}$ are the variances of the resistant and susceptible parents, respectively. The formula proposed by Wright (40) also was used to estimate the minimum number of genes: $N=\left(P_{s}-P_{r}\right)^{2} \times$

Table 2. Mean leaf rust severities of parents, $F_{1}$ plants, and $F_{2}$ populations tested at El-Batan, and least square population means of $\mathrm{F}_{3}$ and $\mathrm{F}_{5}$ lines tested at Ciudad Obregon, derived from a one-way diallel cross involving five resistant and one susceptible wheat genotypes along with checks ${ }^{y}$

\begin{tabular}{|c|c|c|c|c|}
\hline \multirow[b]{2}{*}{ Tested } & \multicolumn{2}{|c|}{ El Batan } & \multicolumn{2}{|c|}{ Ciudad Obregon } \\
\hline & $\mathbf{F}_{1}$ & $\mathbf{F}_{2}$ & $\mathbf{F}_{3}$ & $\mathbf{F}_{5}$ \\
\hline \multicolumn{5}{|c|}{ Susceptible $\times$ resistant crosses } \\
\hline Avocet- $Y r A \times$ Saar & $19.3 \mathrm{~cd}$ & $30.8 \mathrm{~b}$ & 40.4 & 46.0 \\
\hline Avocet- $Y r A \times$ Simorgh & $26.5 \mathrm{bc}$ & $28.4 \mathrm{~b}$ & 44.9 & 45.3 \\
\hline Avocet- $Y r A \times$ Homa & $38.3 \mathrm{~b}$ & $18.5 \mathrm{c}$ & 35.8 & 36.7 \\
\hline Avocet- $Y r A \times$ Parastoo & $6.4 \mathrm{efg}$ & $12.2 \mathrm{c}$ & 34.0 & 24.1 \\
\hline Avocet $-Y r A \times$ Cocnoos & $38.1 \mathrm{~b}$ & $33.3 \mathrm{~b}$ & 44.2 & 40.3 \\
\hline Standard error & $\ldots$ & $\ldots$ & 2.1 & 3.9 \\
\hline \multicolumn{5}{|c|}{ Resistant $\times$ resistant crosses } \\
\hline Saar $\times$ Simorgh & $10.0 \mathrm{def}$ & $6.5 \mathrm{~d}$ & $\ldots$ & 11.4 \\
\hline Saar $\times$ Homa & $3.3 \mathrm{fg}$ & $2.6 \mathrm{efg}$ & $\ldots$ & 10.7 \\
\hline Saar $\times$ Parastoo & $6.4 \mathrm{efg}$ & $3.8 \mathrm{def}$ & $\ldots$ & 8.7 \\
\hline Saar $\times$ Cocnoos & $6.4 \mathrm{efg}$ & $5.9 \mathrm{de}$ & $\begin{array}{l}\cdots \\
\cdots\end{array}$ & 10.7 \\
\hline Simorgh $\times$ Homa & 10.0 efg & $6.5 \mathrm{~d}$ & $\ldots$ & 7.8 \\
\hline Simorgh $\times$ Parastoo & $5.0 \mathrm{efg}$ & $2.5 \mathrm{efg}$ & $\ldots$ & 5.9 \\
\hline Simorgh $\times$ Cocnoos & $6.4 \mathrm{efg}$ & $6.0 \mathrm{de}$ & $\ldots$ & 9.2 \\
\hline Homa $\times$ Parastoo & $1.0 \mathrm{~g}$ & $1.1 \mathrm{~g}$ & $\ldots$ & 2.3 \\
\hline Homa $\times$ Cocnoos & $13.2 \mathrm{de}$ & $4.8 \mathrm{def}$ & $\ldots$ & 5.9 \\
\hline Parastoo $\times$ Cocnoos & $5.0 \mathrm{efg}$ & $3.5 \mathrm{defg}$ & $\ldots$ & 2.7 \\
\hline Standard error & $\ldots$ & $\ldots$ & $\ldots$ & 1.1 \\
\hline \multicolumn{5}{|l|}{ Parents } \\
\hline Avocet-YrA & $100.0 \mathrm{ab}^{\mathrm{z}}$ & $100.0 \mathrm{a}$ & 81.2 & 99.8 \\
\hline Saar & $5.0 \mathrm{efg}$ & $1.9 \mathrm{fg}$ & 6.4 & 12.9 \\
\hline Simorgh & $10.0 \mathrm{def}$ & $4.4 \mathrm{def}$ & 6.4 & 10.9 \\
\hline Homa & $1.0 \mathrm{~g}$ & $3.1 \mathrm{defg}$ & 6.9 & 6.5 \\
\hline Parastoo & $1.0 \mathrm{~g}$ & $1.0 \mathrm{~g}$ & 1.9 & 5.4 \\
\hline Cocnoos & $3.3 \mathrm{fg}$ & $1.0 \mathrm{~g}$ & 1.5 & 0.8 \\
\hline Standard error & $\ldots$ & $\ldots$ & 12.7 & 15.5 \\
\hline \multicolumn{5}{|l|}{ Checks } \\
\hline Avocet- $Y r A$ & $\ldots$ & $\ldots$ & 83.2 & 98.9 \\
\hline Avocet + Lr34 & $\ldots$ & $\ldots$ & 10.7 & 10.5 \\
\hline Thatcher & $\ldots$ & $\ldots$ & 75.6 & 79.4 \\
\hline Thatcher+Lr34 & $\begin{array}{l}\cdots \\
\cdots\end{array}$ & $\begin{array}{l}\cdots \\
\cdots\end{array}$ & 1.1 & 1.0 \\
\hline Jupateco S & $\ldots$ & $\ldots$ & 99.4 & 99.9 \\
\hline Jupateco+Lr34 & $\begin{array}{l}\cdots \\
\cdots\end{array}$ & $\begin{array}{l}\cdots \\
\cdots\end{array}$ & 26.4 & 30.2 \\
\hline AC-Nanda & $\ldots$ & $\ldots$ & 38.0 & 32.4 \\
\hline Cook & $\begin{array}{l}\cdots \\
\cdots\end{array}$ & $\begin{array}{l}\cdots \\
\cdots\end{array}$ & 18.8 & 13.9 \\
\hline Saar & $\ldots$ & $\ldots$ & 11.5 & 10.8 \\
\hline Cocnoos & $\ldots$ & $\ldots$ & 1.8 & 2.0 \\
\hline Standard error & $\begin{array}{l}\cdots \\
\cdots\end{array}$ & $\begin{array}{l}\cdots \\
\cdots\end{array}$ & 11.4 & 12.5 \\
\hline
\end{tabular}

${ }^{y}$ Means followed by letters in common within generations do not differ significantly based on Tukey's standardized range test on arcsine transformed data $(P<0.05)$. Range test is not valid for least square means.

${ }^{\mathrm{z}}$ Leaf rust severity recorded when the susceptible check Avocet- $\mathrm{YrA}$ reached 80 to $100 \%$, based on the modified Cobb's scale (22).
$[1.5-2 h(1-h)] / 8\left(V_{F 2}-V_{E}\right)$, where $P_{r}$ and $P_{\mathrm{s}}$ are the mean parental values of the resistant and susceptible parents, respectively, $h=\left(F_{1}-P_{2}\right) /\left(P_{s}-P_{r}\right), V_{F 2}$ is the variance of the $\mathrm{F}_{2}$, and $V_{E}$ is the environmental variance. The formulae are based on the assumptions that resistance genes that segregate in a cross occur in only one parent, segregating resistance genes are not linked, all resistance genes have equal effects, additive-dominance and genotypeenvironment effects do not exist, and dominance is equal at all loci.

\section{RESULTS}

Terminal leaf rust severities of parental genotypes, $F_{1}$ progenies, $F_{2}$ populations, and least-square means of the leaf rust severities of $\mathrm{F}_{3}$ and $\mathrm{F}_{5}$ lines are presented in Table 2. Least square means are the treatment means adjusted for other effects in the experimental design and were used in $F_{3}$ and $F_{5}$ experiments because they were unbalanced for the number of lines in each cross. All resistant parents displayed low levels of terminal leaf rust severities, whereas the susceptible parent exhibited a high severity. Susceptible $\times$ resistant crosses had intermediate average leaf rust severities in all generations. Although the leaf rust severities of the parents varied slightly in generation trials, the correlations $(r)$ between generations were high and ranged between $0.93(P<0.01)$ and $0.97(P<0.01)$.

Susceptible $\times$ resistant crosses. All $F_{1}$ susceptible $\times$ resistant progenies displayed intermediate levels of leaf rust severity (Table 2). The frequency distributions of leaf rust severity of the $\mathrm{F}_{2}, \mathrm{~F}_{3}$, and $\mathrm{F}_{5}$ lines derived from the susceptible $\times$ resistant crosses showed continuous variation, with only a few lines having the leaf rust severities of the resistant and susceptible parents (Table 3). The frequency distributions were significantly skewed, with population means shifting from the midparental values toward the resistant parent (Table 2).

The frequency of the four or three phenotypic groups in the $\mathrm{F}_{3}$ and $\mathrm{F}_{5}$ lines of the susceptible $\times$ resistant crosses are presented in Table 4. Because $\mathrm{F}_{3}$ lines tested at two locations were not identical, frequencies of the four phenotypic groups in $\mathrm{F}_{3}$ also were pooled and tested against the hypotheses of three and four gene ratios. The expected four gene frequencies for testing the segregation ratio in crosses of 'Avocet S' with 'Homa' and 'Parastoo' were modified, assuming that lines that were homozygous for four and three genes could not be distinguished based on the severity phenotype and were grouped into HPTR class. The ratios at both testing sites individually and when pooled were in agreement with the hypothesis of the control of resistance by at least three independent additive genes in cvs. Saar, Simorgh, and Cocnoos, and four independent genes in Homa and Parastoo. The distribu- 
tion of $\mathrm{F}_{5}$ lines in susceptible $\times$ resistant crosses further verified the $\mathrm{F}_{3}$ results.

Resistant-parent intercrosses. The $\mathrm{F}_{5}$ lines of the resistant-parent intercrosses were tested at Ciudad Obregon to study the similarity or diversity of resistance genes in the parents. Although none of the $\mathrm{F}_{5}$ lines resembled the leaf rust severity of the susceptible parent Avocet-YrA, few lines with leaf rust severities higher than those of the parents could be found (Table 3). In crosses of Saar with Homa, Parastoo, and Cocnoos, and in the cross Homa $\times$ Cocnoos, few lines were found with disease severities as high as 50 to $70 \%$. This indicated that, although parental lines have at least one gene in common, the other additive genes were different. Crosses of Simorgh and Homa with Parastoo displayed less segregation for disease severity in both $F_{2}$ and $F_{5}$ generations, indicating that perhaps two additive genes were common in the parents of the respective crosses.

Quantitative genetics analysis. Analyses of variance for the terminal leaf rust severities in all experiments are given in Table 5. In the $\mathrm{F}_{3}$ experiment, only the susceptible $\times$ resistant crosses were in- cluded. In other experiments, all crosses in the diallel mating were tested. The differences among the parental lines, $\mathrm{F}_{1}$ crosses, $\mathrm{F}_{2}$ populations, and $\mathrm{F}_{3}$ and $\mathrm{F}_{3}$ lines were highly significant. The parents versus $F_{1}$ crosses, $\mathrm{F}_{2}$ populations, and $\mathrm{F}_{3}$ and $\mathrm{F}_{5}$ lines were highly significant, which was an indication of a deviation of $F_{1}$ crosses and $\mathrm{F}_{2}, \mathrm{~F}_{3}$, and $\mathrm{F}_{5}$ population means from midparental values. The differences among the check genotypes tested in the $\mathrm{F}_{3}$ and $\mathrm{F}_{5}$ experiments at Ciudad Obregon also were highly significant. GCA mean squares were highly significant in $F_{1}, F_{3}$, and $F_{5}$

Table 3. Frequency distribution of leaf rust severity of $F_{2}$ plants, and $F_{3}$ and $F_{5}$ lines derived from a one-way diallel cross involving five resistant and one susceptible wheat genotypes, when inoculated with Puccinia triticina race MCJ/SP

\begin{tabular}{|c|c|c|c|c|c|c|c|c|c|c|c|c|c|}
\hline \multirow[b]{2}{*}{ Cross, generation } & \multicolumn{12}{|c|}{ No. of plants or lines with disease severity } & \multirow[b]{2}{*}{ Tota } \\
\hline & 1 & 5 & 10 & 20 & 30 & 40 & $\mathbf{5 0}$ & 60 & 70 & 80 & 90 & 100 & \\
\hline \multicolumn{14}{|c|}{ Susceptible $\times$ resistant } \\
\hline \multicolumn{14}{|c|}{ Avocet-YrA $\times$ Saar } \\
\hline $\mathrm{F}_{2}$ & 28 & 35 & 44 & 43 & 38 & 22 & 8 & 23 & 2 & 31 & 4 & 2 & 280 \\
\hline $\mathrm{F}_{3}$ & 1 & 1 & 2 & 20 & 32 & 26 & 23 & 17 & 18 & 3 & 8 & 4 & 155 \\
\hline $\mathrm{F}_{5}$ & 1 & 4 & 8 & 32 & 6 & 14 & 13 & 11 & 14 & 6 & 8 & 6 & 123 \\
\hline \multicolumn{14}{|c|}{ Avocet $-\operatorname{YrA} \times$ Simorgh } \\
\hline $\mathrm{F}_{2}$ & 57 & 41 & 49 & 26 & 21 & 31 & 4 & 23 & 2 & 29 & 4 & 10 & 297 \\
\hline $\mathrm{F}_{3}$ & 1 & 1 & 1 & 16 & 28 & 15 & 14 & 17 & 10 & 6 & 2 & 1 & 112 \\
\hline $\mathrm{F}_{5}$ & 3 & 7 & 8 & 20 & 15 & 20 & 8 & 13 & 4 & 9 & 7 & 6 & 120 \\
\hline \multicolumn{14}{|c|}{ Avocet $-Y r A \times$ Homa } \\
\hline $\mathrm{F}_{2}$ & 85 & 51 & 23 & 22 & 15 & 14 & 2 & 17 & 0 & 12 & 2 & 3 & 246 \\
\hline $\mathrm{F}_{3}$ & 0 & 6 & 4 & 18 & 11 & 8 & 8 & 8 & 4 & 1 & 0 & 0 & 68 \\
\hline $\mathrm{F}_{5}$ & 3 & 21 & 7 & 20 & 15 & 16 & 14 & 6 & 12 & 3 & 3 & 2 & 122 \\
\hline \multicolumn{14}{|c|}{ Avocet- $Y r A \times$ Parastoo } \\
\hline $\mathrm{F}_{2}$ & 72 & 63 & 50 & 26 & 13 & 8 & 1 & 5 & 0 & 2 & 2 & 2 & 244 \\
\hline $\mathrm{F}_{3}$ & 3 & 2 & 9 & 28 & 31 & 11 & 9 & 10 & 6 & 3 & 0 & 0 & 112 \\
\hline $\mathrm{F}_{5}$ & 14 & 8 & 15 & 34 & 11 & 9 & 7 & 10 & 7 & 3 & 3 & 2 & 123 \\
\hline \multicolumn{14}{|c|}{ Avocet $-Y r A \times$ Cocnoos } \\
\hline $\mathrm{F}_{2}$ & 52 & 23 & 23 & 17 & 14 & 29 & 2 & 29 & 1 & 21 & 6 & 11 & 228 \\
\hline $\mathrm{F}_{3}$ & 1 & 1 & 1 & 18 & 19 & 22 & 24 & 18 & 7 & 3 & 1 & 0 & 115 \\
\hline $\mathrm{F}_{5}$ & 4 & 0 & 2 & 24 & 20 & 20 & 11 & 15 & 4 & 9 & 5 & 2 & 116 \\
\hline \multicolumn{14}{|l|}{ Resistant $\times$ resistant } \\
\hline \multicolumn{14}{|l|}{ Saar $\times$ Simorgh } \\
\hline $\mathrm{F}_{2}$ & 67 & 147 & 63 & 33 & 1 & 0 & 0 & 0 & 0 & 0 & 0 & 0 & 311 \\
\hline $\mathrm{F}_{5}$ & 3 & 38 & 41 & 51 & 9 & 0 & 0 & 0 & 0 & 0 & 0 & 0 & 142 \\
\hline \multicolumn{14}{|l|}{ Saar $\times$ Homa } \\
\hline $\mathrm{F}_{2}$ & 229 & 50 & 13 & 6 & 3 & 0 & 0 & 0 & 0 & 0 & 0 & 0 & 301 \\
\hline \multirow{2}{*}{\multicolumn{14}{|c|}{$\begin{array}{l}\Gamma_{5} \\
\text { Saar } \times \text { Parastoo }\end{array}$}} \\
\hline & & & & & & & & & & & & & \\
\hline $\mathrm{F}_{2}$ & 167 & 65 & 23 & 15 & 1 & 0 & 0 & 0 & 0 & 0 & 0 & 0 & 271 \\
\hline $\mathrm{F}_{5}$ & 49 & 11 & 14 & 29 & 16 & 7 & 2 & 1 & 0 & 0 & 0 & 0 & 129 \\
\hline \multicolumn{14}{|l|}{ Saar $\times$ Cocnoos } \\
\hline $\mathrm{F}_{2}$ & 169 & 60 & 29 & 24 & 15 & 4 & 0 & 0 & 0 & 0 & 0 & 0 & 301 \\
\hline $\mathrm{F}_{5}$ & 21 & 25 & 20 & 39 & 11 & 1 & 1 & 0 & 1 & 0 & 0 & 0 & 119 \\
\hline \multicolumn{14}{|l|}{ Simorgh $\times$ Homa } \\
\hline $\mathrm{F}_{2}$ & 126 & 86 & 19 & 16 & 9 & 3 & 4 & 1 & 0 & 0 & 0 & 0 & 264 \\
\hline $\mathrm{F}_{5}$ & 28 & 45 & 23 & 20 & 1 & 0 & 0 & 0 & 0 & 0 & 0 & 0 & 117 \\
\hline Simorgh $\times$ Parasto & & & & & & & & & & & & & \\
\hline $\mathrm{F}_{2}$ & 190 & 67 & 16 & 0 & 0 & 0 & 0 & 0 & 0 & 0 & 0 & 0 & 273 \\
\hline $\mathrm{F}_{5}$ & 45 & 54 & 29 & 10 & 0 & 0 & 0 & 0 & 0 & 0 & 0 & 0 & 138 \\
\hline Simorgh $\times$ Cocno & & & & & & & & & & & & & \\
\hline $\mathrm{F}_{2}$ & 181 & 64 & 31 & 29 & 13 & 5 & 0 & 0 & 0 & 0 & 0 & 0 & 323 \\
\hline $\mathrm{F}_{5}$ & 18 & 24 & 10 & 19 & 4 & 1 & 0 & 0 & 0 & 0 & 0 & 0 & 76 \\
\hline Homa $\times$ Parastoo & & & & & & & & & & & & & \\
\hline $\mathrm{F}_{2}$ & 283 & 6 & 1 & 0 & 0 & 0 & 0 & 0 & 0 & 0 & 0 & 0 & 290 \\
\hline $\mathrm{F}_{5}$ & 83 & 44 & 6 & 0 & 0 & 0 & 0 & 0 & 0 & 0 & 0 & 0 & 133 \\
\hline Homa $\times$ Cocnoos & & & & & & & & & & & & & \\
\hline $\mathrm{F}_{2}$ & 214 & 42 & 23 & 26 & 14 & 0 & 0 & 0 & 0 & 0 & 0 & 0 & 319 \\
\hline $\mathrm{F}_{5}$ & 31 & 35 & 14 & 14 & 2 & 2 & 1 & 0 & 0 & 0 & 0 & 0 & 99 \\
\hline Parastoo $\times$ Cocno & & & & & & & & & & & & & \\
\hline $\mathrm{F}_{2}$ & 228 & 46 & 16 & 18 & 5 & 0 & 0 & 0 & 0 & 0 & 0 & 0 & 313 \\
\hline $\mathrm{F}_{5}$ & 52 & 31 & 18 & 7 & 1 & 0 & 0 & 0 & 0 & 0 & 0 & 0 & 111 \\
\hline
\end{tabular}

${ }^{\mathrm{z}}$ Leaf rust severity data based on the modified Cobb's scale (22) when the susceptible check 'Avocet-YrA' reached 80 to $100 \%$ in susceptible $\times$ resistant crosses, and 12 to 13 days later when it had necrotic leaves in resistant $\times$ resistant crosses (Jupateco+Lr34 check displayed between 50 and $60 \%$ severity at that time). 
diallel experiments, whereas SCA mean squares were significant only in $F_{1}$ and $F_{2}$ diallel experiments. Components of variance ratios were $0.69,0.94$, and 0.98 for the $F_{1}, F_{2}$, and $F_{5}$ diallel experiments, respectively. The components of variance ratio estimated for the $F_{1}$ diallel was relatively smaller than those estimated for the $\mathrm{F}_{2}$ and $\mathrm{F}_{5}$ diallel experiments. This probably was due to greater SCA estimates in the $F_{1}$ experiment. The relatively high estimates for the components of variance ratios indicated that GCA was of major importance in predicting the progeny performance. The greater importance of GCA effects also was evident based on the relatively high correlations between parental means and GCA effects $(r=0.89, P<0.05$ for $\mathrm{F}_{1} ; r=0.94, P<0.01$ for $\mathrm{F}_{2}$; and $r=$ $0.97, P<0.01$ for $\mathrm{F}_{5}$ ). Narrow-sense heritability estimates were $0.67,0.92$, and 0.96 for $F_{1}, F_{2}$, and $F_{5}$ diallel experiments, respectively. Similar to the component of variance ratios, the heritability estimate for the $F_{1}$ diallel was relatively smaller than those for the $\mathrm{F}_{2}$ and $\mathrm{F}_{5}$, probably due to the greater dominance effects estimated in the $\mathrm{F}_{1}$ experiment.

Estimates of GCA effects for parents and SCA for the crosses are given in Table

Table 4. Frequency distribution of leaf rust severity of $\mathrm{F}_{3}$ and $\mathrm{F}_{5}$ lines derived from crosses of the susceptible genotype 'Avocet- $\mathrm{YrA}$ ' with five resistant wheat genotypes, when inoculated with Puccinia triticina race MCJ/SP

\begin{tabular}{|c|c|c|c|c|c|c|c|c|}
\hline \multirow[b]{2}{*}{ Generation/tested in, cross ${ }^{u}$} & \multicolumn{5}{|c|}{ No. of lines with reaction } & \multirow[b]{2}{*}{ No. of genes ${ }^{z}$} & \multirow[b]{2}{*}{$\chi^{2}$} & \multirow[b]{2}{*}{$P$ value } \\
\hline & HPTR $^{v}$ & HPTS $^{w}$ & SegI ${ }^{x}$ & $\operatorname{SegS}^{y}$ & Others & & & \\
\hline \multicolumn{9}{|l|}{$\mathrm{F}_{3} /$ El-Batan } \\
\hline Saar & 1 & 1 & 39 & 37 & $\ldots$ & 3 & 1.51 & $>0.50$ \\
\hline Simorgh & 1 & 2 & 33 & 34 & $\ldots$ & 3 & 2.87 & $>0.25$ \\
\hline Homa & 3 & 1 & 51 & 25 & $\ldots$ & 4 & 1.79 & $>0.50$ \\
\hline Parastoo & 3 & 1 & 44 & 20 & $\ldots$ & 4 & 2.18 & $>0.50$ \\
\hline Cocnoos & 0 & 0 & 26 & 26 & $\ldots$ & 3 & 3.11 & $>0.25$ \\
\hline \multicolumn{9}{|l|}{$\mathrm{F}_{3} /$ Ciudad Obregon } \\
\hline Saar & 3 & 3 & 93 & 56 & $\ldots$ & 3 & 1.43 & $>0.50$ \\
\hline Simorgh & 3 & 1 & 60 & 48 & $\ldots$ & 3 & 1.49 & $>0.50$ \\
\hline Homa & 4 & 1 & 43 & 18 & $\ldots$ & 4 & 2.63 & $>0.25$ \\
\hline Parastoo & 5 & 1 & 71 & 35 & $\ldots$ & 4 & 0.80 & $>0.99$ \\
\hline Cocnoos & 4 & 1 & 58 & 52 & $\ldots$ & 3 & 4.34 & $>0.10$ \\
\hline \multicolumn{9}{|l|}{$\mathrm{F}_{3} /$ pooled } \\
\hline Saar & 4 & 4 & 132 & 93 & $\ldots$ & 3 & 0.08 & $>0.99$ \\
\hline Simorgh & 4 & 3 & 93 & 82 & $\ldots$ & 3 & 1.34 & $>0.50$ \\
\hline Homa & 7 & 2 & 94 & 43 & $\ldots$ & 4 & 3.78 & $>0.25$ \\
\hline Parastoo & 8 & 2 & 115 & 55 & $\ldots$ & 4 & 2.57 & $>0.25$ \\
\hline Cocnoos & 4 & 1 & 84 & 78 & $\ldots$ & 3 & 2.78 & $>0.25$ \\
\hline \multicolumn{9}{|l|}{$\mathrm{F}_{5} /$ Ciudad Obregon } \\
\hline Saar & 6 & 10 & $\ldots$ & $\ldots$ & 107 & 3 & 2.00 & $>0.25$ \\
\hline Simorgh & 14 & 11 & $\ldots$ & $\ldots$ & 95 & 3 & 1.89 & $>0.25$ \\
\hline Homa & 20 & 5 & $\ldots$ & $\ldots$ & 97 & 4 & 0.52 & $>0.75$ \\
\hline Parastoo & 15 & 5 & $\ldots$ & $\ldots$ & 103 & 4 & 3.56 & $>0.10$ \\
\hline Cocnoos & 4 & 8 & $\ldots$ & $\ldots$ & 104 & 3 & 4.22 & $>0.10$ \\
\hline
\end{tabular}

"Avocet-YrA crossed with genotypes listed.

${ }^{\mathrm{v}}$ Homozygous for the parental type resistance (homozygous for all resistance alleles).

${ }^{\mathrm{w}}$ Homozygous for the parental type or higher susceptibility (homozygous lacking all resistance alleles).

${ }^{\mathrm{x}}$ Either segregating or homozygous for disease levels higher that that of the resistant parent but less than that of the susceptible parent (homozygous for at least one resistance allele).

${ }^{y}$ Segregating with disease levels reaching the susceptible parent response (heterozygous for at least one locus and homozygous for susceptibility alleles at other loci).

${ }^{z}$ Tested for segregation of the indicated number of genes. The ratio used in $\mathrm{F}_{3}$ was 0.0156 HPTR:0.0156 HPTS:0.5625 SegI:0.4062 SegS expected for the segregation of three additive genes and 0.0507 HPTR:0.0039 HPTS:0.6328 SegI:0.3125 SegS for the segregation of four genes. The ratio used in $\mathrm{F}_{5}$ was 0.0837 HPTR:0.0837 HPTS:0.8327 others for the segregation of three genes and 0.1884 HPTR:0.0366 HPTS:0.775 others for the segregation of four genes. Four gene ratios are adjusted based on the combined frequency of lines homozygous for three and four genes into the HPTR category, assuming that it was not possible to distinguish such lines based on rust severity response.

Table 5. Mean squares (MS)for the arcsine-transformed terminal leaf rust severity of parents, $\mathrm{F}_{1}$ crosses, $\mathrm{F}_{2}$ populations, and $\mathrm{F}_{5}$ lines derived from a oneway diallel cross, involving susceptible genotype, 'Avocet- $Y r A$ ' and five resistant wheat genotypes, and $\mathrm{F}_{3}$ of susceptible $\times$ resistant crosses, when inoculated with Puccinia triticina race MCJ/SP

\begin{tabular}{|c|c|c|c|c|c|c|c|}
\hline \multirow[b]{3}{*}{$\mathbf{S V}^{\mathbf{z}}$} & \multicolumn{7}{|c|}{ Generation $^{y}$} \\
\hline & \multirow[b]{2}{*}{ df } & \multirow{2}{*}{$\begin{array}{c}\mathrm{F}_{1} \\
\mathrm{MS}\end{array}$} & \multirow{2}{*}{$\frac{\mathrm{F}_{2}}{\mathrm{MS}}$} & \multicolumn{2}{|c|}{$\mathbf{F}_{3}$} & \multicolumn{2}{|c|}{$\mathbf{F}_{5}$} \\
\hline & & & & df & MS & df & MS \\
\hline Block & 2 & $<0.001$ & $<0.001$ & 2 & 0.036 & 9 & 0.008 \\
\hline Treatment (T) & 20 & $0.309 * *$ & $0.317 * *$ & 20 & $0.545^{* *}$ & 30 & $1.850^{* *}$ \\
\hline Parents & 5 & $0.979 * *$ & $1.020 * *$ & 5 & $0.479 * *$ & 5 & $1.450 * *$ \\
\hline Parents vs. crosses & 1 & $0.074 * *$ & $0.073 * *$ & 1 & $0.693 * *$ & 1 & $0.132 * *$ \\
\hline Crosses & 14 & $0.086 * *$ & $0.083 * *$ & 4 & $0.382 * *$ & 14 & $0.535^{* *}$ \\
\hline GCA & 5 & $0.187 * *$ & $0.221 * *$ & $\ldots$ & $\ldots$ & 5 & $0.116^{* *}$ \\
\hline $\mathrm{SCA}$ & 9 & $0.031 * *$ & $0.007 * *$ & $\ldots$ & $\ldots$ & 9 & 0.001 \\
\hline Crosses $\times$ block & 28 & 0.004 & 0.001 & $\ldots$ & $\ldots$ & $\ldots$ & $\ldots$ \\
\hline Checks & $\ldots$ & $\ldots$ & $\ldots$ & 9 & $0.854 * *$ & 9 & $2.554 * *$ \\
\hline Line/T & $\ldots$ & 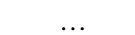 & $\ldots$ & 557 & 0.053 & 1765 & $0.048 * *$ \\
\hline Error & 40 & 0.002 & $<0.001$ & 31 & 0.066 & 105 & 0.005 \\
\hline
\end{tabular}

y $*$ and $* *=$ Significant at $P<0.05$ and 0.01 , respectively.

${ }^{\mathrm{z}} \mathrm{SV}=$ source of variation, GCA = general combining ability, and SCA = specific combining ability. 
6. The $\mathrm{F}_{1}$ crosses, $\mathrm{F}_{2}$ populations, and $\mathrm{F}_{5}$ lines involving parents with negative GCA effects were more resistant than the average of the respective generations, whereas significant positive GCA indicated greater susceptibility. Parastoo had the greatest negative GCA in all experiments that was significant in $F_{1}$ and $F_{5}$, and highly significant in $\mathrm{F}_{2}$. This indicated that the most resistant $F_{1}$ progenies, $F_{2}$ populations, or $F_{5}$ lines on average had Parastoo as one of the parents. The relative values of GCA effects were slightly inconsistent across generations.

The SCA of the $F_{1}$ progenies, $F_{2}$ populations, and $\mathrm{F}_{5}$ lines are presented in Table 6. In crosses involving the susceptible parent, Parastoo had the greatest negative SCA effect in all generations $(\mathrm{SCA}=-12.11, P$ $<0.01$ for $\mathrm{F}_{1}$; $\mathrm{SCA}=-7.74, P<0.01$ for $\mathrm{F}_{2}$; and $\mathrm{SCA}=-4.30, P<0.01$ for $\mathrm{F}_{5}$ ). This indicated that Parastoo had the greatest reduction in average terminal leaf rust severity when crossed with the susceptible parent. In the resistant parent intercrosses, the cross Saar $\times$ Cocnoos had significant and highly significant negative SCA effect in $\mathrm{F}_{2}$ and $\mathrm{F}_{5}$, respectively $(\mathrm{SCA}=-3.24, P$ $<0.05$ for $\mathrm{F}_{2}$ and SCA $=-2.52, P<0.01$ for $\mathrm{F}_{5}$ ). As for the GCA effects, slight inconsistency in SCA effects of the crosses also was observed across generations.

Estimates of the minimum numbers of additive genes in the resistant parental lines based on the $\mathrm{F}_{5}$ data from the susceptible $\times$ resistant crosses are presented in Table 7. The estimates based on the two formulae were between 2.17 and 4.02 .

\section{DISCUSSION}

The resistant parents included in this study were selected at CIMMYT, Mexico for seedling and adult plant compatibility, characterized by a high infection type, accompanied by low adult plant leaf rust severity to common Mexican races of $P$. triticina (32). They all displayed moderately susceptible to susceptible infection types in field evaluations, confirming the compatible nature of the host-pathogen interaction that is a known feature of partial (21) or slow-rusting resistance (6).

$F_{1}$ progenies showed intermediate levels of terminal leaf rust severity, significantly higher than those of the resistant parents. This implied that adult-plant resistance to leaf rust in the evaluated genotypes was incompletely dominant. Segregation analyses indicated the presence of at least three to four genes having additive effects in each of the resistant parents. When quantitative methods of analysis were used, the estimates of the number of additive genes ranged between 2.17 and 4.02. These numbers are different from those estimated by the Mendelian method of segregation analysis. However, they are in agreement with the involvement of more than a single locus in the inheritance of adult-plant resistance in the genotypes. The difference in the estimated numbers may have been due to the fact that estimates based on the quantitative methods of genetic analysis may be biased and influenced by the visual estimates of disease severity (39).

All resistant parents displayed leaf tip necrosis phenotype, which is known to be either pleiotropic or tightly linked to the slow-rusting adult-plant resistance gene
Lr34 (29). Moreover, the resistant parents were derived from intercrosses of Lr34carrying genotypes. Therefore, we conclude that $L r 34$ was one of the genes present in all parents. The frequency distribution of the leaf rust severity in $F_{3}$ and $F_{5}$ lines derived from the susceptible $\times$ resistant crosses were skewed, with population means shifting toward the resistant parent. This may have resulted from unequal effects of $L r 34$ and additive genes.

The adult-plant resistance gene Lr46 is likely to be present in Saar and Simorgh. They both are three-way cross derivatives having Sonoita 81 as one of the parents. Sonoita 81 shares common parentage with the Mexican cv. Pavon 76 (coefficient of parentage $=0.48$; estimated by the International Wheat Information System; 10), which has Lr46. However, this hypothesis needs to be further investigated.

Although we assume that gene Lr34 is common in all resistant parents, some of the $F_{5}$ lines derived from intercrosses of resistant parents had disease severities considerably higher than their parental responses. This indicated that some of the additive genes in the parents were nonallelic; therefore, they can be accumulated into new breeding lines to further enhance the level of resistance. The transgression for the maximum infection level varied among the resistant $\times$ resistant crosses. The high-

Table 7. Minimum number of effective additive genes for resistance to Puccinia triticina race $\mathrm{MCJ} / \mathrm{SP}$ in five wheat genotypes

\begin{tabular}{lcc}
\hline & \multicolumn{2}{c}{ Number of genes estimated based on ${ }^{\mathbf{z}}$} \\
\cline { 2 - 3 } Avocet-YrA crossed with & Formula 1 & Formula 2 \\
\hline Saar & 2.18 & 2.19 \\
Simorgh & 2.42 & 2.50 \\
Homa & 3.20 & 2.17 \\
Parastoo & 3.21 & 3.09 \\
Cocnoos & 4.02 & 2.50 \\
\hline
\end{tabular}

${ }^{\mathrm{z}}$ Formulae 1 and 2 are based on Bjarko and Line (3) and Wright (40), respectively.

Table 6. Estimates of general (on diagonal) and specific combining ability for the terminal leaf rust severity in $\mathrm{F}_{1}$ (top), $\mathrm{F}_{2}$ (middle), and $\mathrm{F}_{5}$ (bottom) generations of a one-way diallel cross, involving susceptible genotype 'Avocet- $Y r A$ ' and five resistant wheat genotypes ${ }^{z}$

\begin{tabular}{|c|c|c|c|c|c|c|}
\hline Parent & Avocet-YrA & Saar & Simorgh & Homa & Parastoo & Cocnoos \\
\hline Avocet-YrA & $\begin{array}{l}16.00 * * \\
16.94 * * \\
24.88^{*}\end{array}$ & $\begin{array}{c}-4.45 \\
4.25^{*} \\
0.04\end{array}$ & $\begin{array}{l}-0.61 \\
1.79 \\
3.33 * *\end{array}$ & $\begin{array}{l}9.05 * * \\
-4.05 * \\
-2.20 *\end{array}$ & $\begin{array}{r}-12.11 * * \\
-7.74 * * \\
-4.30 * *\end{array}$ & $\begin{array}{l}8.13^{*} \\
5.75^{* *} \\
3.12 * *\end{array}$ \\
\hline Saar & $\begin{array}{l}\cdots \\
\cdots \\
\cdots\end{array}$ & $\begin{array}{c}-4.75^{*} \\
-1.47 \\
0.68\end{array}$ & $\begin{aligned} & 3.46 \\
&-1.78 \\
&-3.03 * *\end{aligned}$ & $\begin{array}{c}-4.86 \\
-1.54 \\
2.41 *\end{array}$ & $\begin{array}{l}8.63 * * \\
2.31 \\
3.10 * *\end{array}$ & $\begin{array}{l}-2.78 \\
-3.24 * \\
-2.52 * *\end{array}$ \\
\hline Simorgh & $\begin{array}{l}\cdots \\
\ldots \\
\cdots\end{array}$ & $\begin{array}{l}\cdots \\
\cdots \\
\cdots\end{array}$ & $\begin{array}{l}-1.91 \\
-1.36 \\
-4.38\end{array}$ & $\begin{array}{r}-1.36 \\
2.38 \\
-0.45\end{array}$ & $\begin{array}{l}4.13 \\
0.83 \\
0.80\end{array}$ & $\begin{array}{l}-5.61 * \\
-3.22 * \\
-0.64\end{array}$ \\
\hline Homa & $\begin{array}{l}\cdots \\
\cdots \\
\cdots\end{array}$ & $\begin{array}{l}\cdots \\
\cdots \\
\cdots\end{array}$ & $\begin{array}{l}\cdots \\
\cdots \\
\cdots\end{array}$ & $\begin{aligned} & 0.08 \\
- & 5.46^{* * *} \\
- & 6.89\end{aligned}$ & $\begin{array}{c}-1.86 \\
3.54 * \\
0.30\end{array}$ & $\begin{array}{l}-0.95 \\
-0.33 \\
-0.05\end{array}$ \\
\hline Parastoo & $\begin{array}{l}\cdots \\
\cdots \\
\cdots\end{array}$ & $\begin{array}{l}\cdots \\
\ldots \\
\ldots\end{array}$ & $\begin{array}{l}\ldots \\
\ldots \\
\ldots\end{array}$ & $\begin{array}{l}\cdots \\
\cdots \\
\ldots\end{array}$ & $\begin{array}{c}-10.41 * \\
-8.14 * * \\
-9.91 *\end{array}$ & $\begin{array}{l}1.21 \\
1.05 \\
0.09\end{array}$ \\
\hline Cocnoos & $\begin{array}{l}\cdots \\
\cdots \\
\ldots\end{array}$ & $\begin{array}{l}\cdots \\
\cdots \\
\ldots\end{array}$ & $\begin{array}{l}\cdots \\
\cdots \\
\ldots\end{array}$ & $\begin{array}{l}\cdots \\
\ldots \\
\ldots\end{array}$ & $\begin{array}{l}\cdots \\
\cdots \\
\ldots\end{array}$ & $\begin{array}{r}1.00 \\
-0.50 \\
-4.37\end{array}$ \\
\hline
\end{tabular}

$\mathrm{z} *$ and $* *=$ Significantly different from zero at $P<0.05$ and 0.01 , respectively. 
est levels of leaf rust severities (50 to 70\%) in the $\mathrm{F}_{5}$ generation was found for the cross Saar $\times$ Cocnoos, whereas the cross Homa $\times$ Parastoo gave rise to lines with no more than $10 \%$ leaf rust severities. Saar and Cocnoos also share less common parentage based on the pedigree information and seem to carry different genes apart from Lr34, which is common to both. In other words, between Saar and Cocnoos, other than gene Lr34, two additional genes could be present in each parent. They share Kauz*2/Trap//Kauz as a common parent. The $\mathrm{F}_{5}$ lines in the resistant-parent intercrosses with terminal leaf rust severities as high as $60 \%$ probably are those with $\operatorname{Lr} 34$ alone. This further indicated that a single additive leaf rust adult-plant resistance gene does not provide acceptable level of resistance. This was in accordance with the previously published reports $(18,31)$ of leaf rust severities of up to 50 to $60 \%$ when Lr34 was deployed alone. A further example involves gene Lr46. Singh et al. (34) reported leaf rust severities of up to $60 \%$ when the $L r 46$ gene was present alone. The leaf rust severities of the three $L r 34$ isogenic lines in Thatcher, Jupateco, and Avocet backgrounds, in $\mathrm{F}_{3}$ and $\mathrm{F}_{5}$ experiments, were not higher than $30 \%$. The data presented in Table 2 are from an evaluation made when Avocet-YrA had just reached 80 to $100 \%$ rust severity. The data on resistant $\times$ resistant crosses (Table 3 ) were recorded about 12 to 13 days later to allow a higher variation in severity of the lines. Thatcher $+L r 34$ is a very late line in Ciudad Obregon and the expression of Lr34 may be different. Moreover, previous studies on this line (Thatcher+Lr34 line RL6058) have determined involvement of factors other than just Lr34 (31).

Additive gene effects appeared to be more important than nonadditive gene effects in the inheritance of adult-plant resistance to leaf rust, as indicated by the quantitative analysis in our study. The GCA, which represents the average performance of a genotype and mainly is reflective of the additive gene effects, was significant in all generations. The SCA also was found to be significant in $\mathrm{F}_{1}$ and $\mathrm{F}_{2}$, but the mean squares for SCA were much smaller than the mean squares of GCA. Moreover, the components of variance ratio, proposed by Baker (2), were 0.67 for $F_{1}$ and close to unity for $F_{2}$ and $F_{5}$. Our conclusion that additive gene effects contributed the most in the inheritance of adult-plant resistance to leaf rust is consistent with results from previous studies on race-nonspecific adult-plant resistance to leaf rust in other wheat genotypes $(8,20,27)$.

In addition to the additive gene effects, there also was evidence for the presence of significant nonadditive gene effects in our study. The model that is used in the combining ability analysis assumes that epistasis and genotype-environment effects are negligible. Therefore, any nonadditive effect is referred to as dominance. The significant parent-crosses effect in analysis of variance for all generations indicated the presence of a significant deviation of $F_{1}$ crosses, and $F_{2}$ and $F_{5}$ population mean values from midparental values. The frequency distributions of the leaf rust severities of the susceptible $\times$ resistant crosses also were skewed. Moreover, significant SCA effects in $F_{1}$ and $F_{2}$ and smaller components of variance ratio estimated for $F_{1}$ pointed to the presence of nonadditive gene effects. Messmer et al. (20) also reported the presence of significant dominance effects in the inheritance of adult-plant resistance to leaf rust in wheat.

It also should be noted that, because leaf rust severity assessment was based on a visual scale, there could be the possibility of overestimation of nonadditive effects. The application of a quantitative genetic approach in the study of gene effects has been argued (39) for having underestimates of additive variance and overestimates of nonadditive variance. Therefore, we relate the significant nonadditive variance estimated in this analysis, at least in part, to the overestimation of such effects due to the visual scale of disease assessment that was used. Gene Lr34 is known to interact strongly with other genes (11). This interaction in lines with Lr34 in association with one or more additional genes could produce a level of resistance greater than expected from a simple additive effect. The nonadditive effects in this study may have been caused by this enhancement effect of Lr34.

A high level of adult-plant resistance to leaf rust in the resistant parents included in our study was found to be inherited by a few genes, with additive gene effects being the major contributor. Our results were in agreement with the previously published reports $(3,4,35,36)$ of the inheritance of adult-plant resistance to leaf rust to be the result of additive interactions of a few genes. Resistance of some widely grown cultivars carrying Lr34 and additional genes having additive effects has remained effective for a long period of time (36). A high level of resistance in the resistant parents included in our study, therefore, is expected to be of a durable nature.

Transgressive segregation giving rise to lines with higher levels of resistance than those of parents was observed in the intercrosses of resistant parents. Other researchers $(4,8,17)$ also reported the presence of transgressive segregation for latent period and receptivity of leaf rust in wheat. Incorporating the additive genes from different sources, therefore, will be possible through intercrossing adult-plant resistant genotypes carrying different additive genes. It has been demonstrated $(32,33)$ that incorporating these additive genes in high-yielding cultivars by means of topcrossing or limited back-crossing may result in the achievement of resistance levels reaching near-immunity while maintaining or even increasing the actual yield potential.

The estimates of the narrow-sense heritability ranged from 0.67 to 0.97 among generations. This indicated that the terminal leaf rust severity in the field was moderately to highly heritable. Other researchers $(7,9,16,27)$ reported moderate to high heritability for the latent period and the area under the leaf rust progress curve. Kuhn et al. (16), based on the higher heritability estimates of latent period over pustule size, suggested that selection could be done for a longer latent period. Kolmer and Liu (15), however, recommended the use of direct genetic analysis, because latent period may not always be predictive of adult-plant resistance to leaf rust. It can be concluded from the results of our study that breeding for adult-plant resistance would be possible by selection for disease severity at the critical stages of growth. Selection must be done under an epidemic of $P$. triticina with a high spectrum of virulence for any known seedling resistance gene that may act epistatically and mask the effect of adult-plant resistance genes. It also should be noted that selection pressure for plants with very low leaf rust severities in the early segregating generations may result in deleting the heterozygous plants that would be capable of giving progenies with higher levels of resistance.

\section{LITERATURE CITED}

1. Allan, R. E. 1980. Wheat. In: Hybridization of Crop Plants. R. W. Fehr and H. H. Hadley, eds. American Society of Agronomy and Crop Science Society of America Publishers, Madison, WI.

2. Baker, R. J. 1978. Issues in diallel analysis. Crop Sci. 18:533-536.

3. Bjarko, M. E., and Line, R. E. 1988. Heritability and number of genes controlling leaf rust resistance in four cultivars of wheat. Phytopathology 78:457-461.

4. Broers, L. H. M., and Jacobs, T. H. 1989. The inheritance of host plant effect on latency period of wheat leaf rust in spring wheat. II: Number of segregating factors and evidence for transgressive segregation in $\mathrm{F}_{3}$ and $\mathrm{F}_{5}$ generations. Euphytica 44:207-214.

5. Burrow, M. D., and Coors, J. G. 1994. Diallel: A microcomputer program for the simulation and analysis of diallel crosses. Agron. J. 86:154-158.

6. Caldwell, R. M. 1968. Breeding for general and/or specific plant disease resistance. Pages 263-272. in: Proc. 3rd Int. Wheat Genet. Symp. K. W. Finlay and K. W. Shephard, eds. Australian Academy of Science, Canberra, Australia.

7. Das, M. K., and Griffey, C. A. 1994. Diallel analysis of adult plant resistance to powdery mildew in wheat. Crop Sci. 34:948-952.

8. Das M. K., Rajaram, S., Kronstad, W. E., Mundt, C. C., and Singh, R. P. 1993. Associations and genetics of three components of slow rusting in leaf rust of wheat. Euphytica 68:99-109.

9. Das, M. K., Rajaram, S., Mundt, C. C., and Kronstad, W. E. 1992. Inheritance of slowrusting to leaf rust in wheat. Crop Sci. 32:1452-1456. 
10. Fox, P. N., Magana, R. I., Lopez, C., Sanchez, H., Herrara, R., Vicarte, V., White, J. W., Skovmand, B., and Mackay, M. C. 1997. International Wheat Information System (IWIS), Version 2. CIMMYT, Mexico, D.F.

11. German, S. E., and Kolmer, J. A. 1992. Effect of the gene Lr34 in the enhancement of resistance to leaf rust of wheat. Theor. Appl. Genet. 84:97-105.

12. Griffing, B. 1956. Concept of general and specific combining ability in relation to diallel crossing systems. Aust. J. Biol. Sci. 9:463493.

13. Khan, M. A., Trevathan, L. E., and Robbins, J. T. 1997. Quantitative relationship between leaf rust and wheat yield in Mississippi. Plant Dis. 81:769-772

14. Kolmer, J. A. 1996. Genetics of resistance to wheat leaf rust. Annu. Rev. Phytopathol. 34:435-455.

15. Kolmer, J. A., and Liu, J. Q. 2001. Simple inheritance to leaf rust in two wheat cultivars. Plant Pathol. 50:546-551.

16. Kuhn, R. C., Ohm, H. W., and Shaner, G. 1980. Inheritance of slow leaf-rusting resistance in Suwon 85 wheat. Crop Sci. 20:655-659.

17. Lee, T. S., and Shaner, G. 1985. Transgressive segregation of length of latent period in crosses between slow leaf-rusting wheat cultivars. Phytopathology 75:643-647.

18. McIntosh, R. A. 1992. Pre-emptive breeding to control wheat rusts. Euphytica 63:103-113.

19. McIntosh, R. A., Hart, G. E., Devos, K. M., Gale, M. D., and Rogers, W. J. 1998. Catalogue of gene symbols for wheat, vol. 5 In: Proc. 9th. Int. Wheat Genet. Symp. A. E. Slinkard, ed. University of Saskatchewan, Extension Press, Saskatoon, Canada.

20. Messmer, M. M., Seyfarth, R., Keller, M., Schachermayer. G., Winzeler. M., Zanetti, S., Feuillet, C., and Keller, B. 2000. Genetic analysis of durable leaf rust resistance in winter wheat. Theor. Appl. Genet. 100:419-431.
21. Parlevliet, J. E. 1988. Strategies for the utilization of partial resistance for the control of cereal rusts. Pages 48-62 in: Breeding Strategies for Resistance to the Rusts of Wheat. N. W. Simmonds and S. Rajaram, eds. CIMMYT, Mexico, D.F

22. Peterson, R. F., Campbell, A. B., and Hannah, A. E. 1948. A diagrammatic scale for estimating rust severity on leaves and stems of cereals. Can. J. Res. C. 26:496-500.

23. Poehlman, J. M., and Sleper, D. A. 1995. Breeding Field Crops, 4th ed. Iowa State University, Ames.

24. Roelfs, A. P., Singh, R. P., and Saari, E. E. 1992. Rust Diseases of Wheat: Concepts and Methods of Disease Management. CIMMYT, Mexico, D.F.

25. Samborski, D. J. 1984. Wheat leaf rust. Pages 39-60 in: The Cereal Rusts, Vol. 2. A. P. Roelfs and W. R. Bushnell, eds. Academic Press Inc., Orlando, FL.

26. Scott, R. A., and Milliken, G. A. 1993. A SAS program for analyzing augmented randomized complete-block designs. Crop Sci. 33:865867.

27. Shaner, G., Buechley, G., and Nyquist, W. E. 1997. Inheritance of latent period of Puccinia recondita in wheat. Crop Sci. 37:748-756.

28. Singh, R. P. 1991. Pathogenicity variations of Puccinia recondita f. sp. tritici in wheatgrowing areas of Mexico during 1988 and 1989. Plant Dis. 75:790-794

29. Singh, R. P. 1992. Association between gene Lr34 for leaf rust resistance and leaf tip necrosis in wheat. Crop Sci. 32:874-878.

30. Singh, O., Gowda, C. L. L., Sethi, S. C. Dasgupta, T., and Smithson, J. B. 1992. Genetic analysis of agronomic characters in chickpea. I. Estimates of genetic variances from diallel mating designs. Theor. Appl. Genet. 83:956-962.

31. Singh, R. P., and Gupta, A. K. 1992. Expression of wheat leaf rust resistance gene Lr34 in seed- lings and adult plants. Plant Dis. 76:489-491.

32. Singh, R. P., Huerta-Espino, J., and Rajaram, S. 2000. Achieving near-immunity to leaf and stripe rusts in wheat by combining slow rusting resistance genes. Acta Phytopathol. Entomol. Hung. 35:133-139.

33. Singh, R. P., Huerta-Espino, J., and William, M. 2001. Slow rusting genes based resistance to leaf and yellow rusts in wheat: genetics and breeding at CIMMYT. Pages 103-108 in: Proc. 10th Assem. Wheat Breed. Soc. Australia, Mildura, Australia. Wheat Breed. Soc. Aust. Inc., Mildura, Australia.

34. Singh, R. P., Mujeeb-Kazi, A., and HuertaEspino, J. 1998. Lr46: A gene conferring slow-rusting resistance to leaf rust in wheat. Phytopathology 88:890-894.

35. Singh, D., Park, R. F., and McIntosh, R. A. 2001. Inheritance of seedling and adult plant resistance to leaf rust of selected Australian spring and English winter wheat varieties. Plant Breed. 120:503-507.

36. Singh, R. P., and Rajaram, S. 1992. Genetics of adult plant resistance to leaf rust in 'Frontana' and three CIMMYT wheats. Genome 35:24-31

37. Smale, M., Singh, R. P., Sayre, K., Pingali, P., Rajaram, S., and Dubin, H. J. 1998. Estimating the economic impact of breeding nonspecific resistance to leaf rust in modern bread wheats. Plant Dis. 82:1055-1061.

38. Steel, R. G. D., Torrie, J. H., and Dickey, D. A. 1997. Principles and Procedures of Statistics: A Biometrical Approach. 3rd ed. Mcgraw Hill, Inc., New York.

39. Vanderplank, J. E. 1984. Pages 26-27 in: Disease Resistance in Plants, 2nd ed. Academic Press, Inc., London.

40. Wright, S. 1968. The genetics of quantitative variability. Pages 351-436 in: Evolution and Genetics of Populations. Vol. 1. Genetic and Biometric Foundations. University of Chicago Press, Chicago. 